DOI: $10.2478 / \mathrm{v} 10047-012-0003-7$

\title{
APPLICATION OF SYNCHRONOUS BRUSHLESS MOTORS IN ELECTRIC HAND TOOLS
}

\author{
J. Dirba ${ }^{1}$, L. Lavrinovicha ${ }^{1}$, N. Levin ${ }^{2}$, V. Pugachev ${ }^{2}$ \\ ${ }^{1}$ Riga Technical University, \\ 1 Kronvalda Blvd., Riga, LV-1010, LATVIA \\ e-mail:dirba@eef.rtu.lv \\ ${ }^{2}$ Institute of Physical Energetics, \\ 21 Aizkraukles Str., Riga, LV-1006, LATVIA \\ e-mail:magneton@edi.lv
}

\begin{abstract}
In the paper, the possibilities to apply synchronous brushless motors in the electric hand tools are considered. The potential of such motors is estimated in a wide range of characteristics. In particular, estimation is made for the electric hand plane with a synchronous motor having outer rotor and excitation from permanent magnets. plane.

Key words: synchronous brushless motor, electric hand tools, electric hand
\end{abstract}

\section{INTRODUCTION}

In recent years an increased interest has been observed in the synchronous brushless (SBL) motors. This interest refers both to the theoretical investigations of such a motor and to its practical realization.

Conducting research into the SBL motors, investigators apply different approaches. One of them is based on the conventional DC regulation using principles of the general theory of synchronous machines, while another approach considers the operation of such a motor with semiconductor switches and position sensors in a continuous transient process described by differential equations. Each of these approaches has its own advantages and disadvantages. Lately, the SBL motor is more often considered as a synchronous machine that operates in specific mode; in this case the analysis is comparatively simple and visual [1,2].

One of the areas where a SBL motor could successfully be applied is electric hand tools. It is found that the application of brushed motors for this purpose has definite disadvantages - mainly associated with the collector and brushes (low level of safety, short lifetime, etc.) [3].

In this paper, the possibility to apply SBL motors (instead of brushed ones) in electric hand planes is analyzed.

\section{BASIC EQUATIONS OF THE SBL MOTORS}

Depending on the applied control scheme of switches, it is possible to set different operating modes for a SBL motor, e.g., when at changing the motor load and rotation frequency the angle $\theta$ between the EMF and the supply voltage spatial 
vectors or the angle $\varepsilon$ between the axes of armature and excitation MMFs remains constant.

If the SBL motor operates with $\theta=$ const, the expressions for all basic electromagnetic values can be obtained from the vector diagram of synchronous motor [2] as

$$
\begin{aligned}
& I_{1}=\sqrt{\frac{U^{2}-2 U I_{2} \omega L \cos \theta+\omega^{2} I_{2}^{2} L^{2}}{R_{1}^{2}+\sigma^{2} \omega^{2} L^{2}}}, \\
& M=\frac{m p I_{2} L}{R_{1}^{2}+\sigma^{2} \omega^{2} L^{2}}\left[U\left(\sigma \omega L \sin \theta+R_{1} \cos \theta\right)-I_{2} \omega L R_{1}\right], \\
& P=m I_{2} \omega L\left[\frac{U\left(\sigma \omega L \sin \theta+R_{1} \cos \theta\right)-I_{2} \omega L R_{1}}{R_{1}^{2}+\sigma^{2} \omega^{2} L^{2}}\right], \\
& t q \phi=\frac{\omega L\left[\sigma U-I_{2}\left(\sigma \omega L \cos \theta+R_{1} \sin \theta\right)\right]}{U R_{1}+I_{2} \omega L\left(\sigma \omega L \sin \theta-R_{1} \cos \theta\right)},
\end{aligned}
$$

where $\omega-$ the armature current angular frequency proportional to the rotor RPM

$$
n=\frac{\omega}{2 \pi p} \text {; }
$$

$p$ - the number of pole pairs;

$m$ - the number of phases;

$L$ - the inductance correspondent to the flux of armature reaction;

$R_{1}$ - the active resistance of the armature winding;

$I_{2}$ - the current of the excitation winding reduced to the armature winding;

$I_{1}$ - the current of the armature winding;

$M$ - the electromagnetic torque of the motor;

$P$ - the electromagnetic power of the motor;

$U$ - the phase voltage applied to the armature winding;

$\varphi$ - the phase shift angle between the armature voltage and current;

$\sigma-$ the dissipation factor of the armature winding.

Equations (1-4) have been obtained for a synchronous machine with nonsalient poles. The same assumptions can be referred to a SBL motor with permanent magnets. As known, the motors with permanent magnets have no excitation winding. Therefore, current $I_{2}$ in these equations is calculated as equivalent, i.e. providing the same basic harmonic of magnetic flux in the motor as is obtained owing to permanent magnets. The methodology for determination of this equivalent current for a motor with permanent magnets is given in [4].

The same as for $\theta=$ const mode, the vector diagram allows the SBL motor expressions to be obtained for the operation mode with $\varepsilon=$ const :

$$
I_{1}=\frac{-I_{2} \omega L\left(\sigma \omega L \cos \varepsilon+R_{1} \sin \varepsilon\right)}{R_{1}^{2}+\sigma^{2} \omega^{2} L^{2}}+
$$




$$
+\frac{\sqrt{I_{2}^{2} \omega^{2} L^{2}\left(R_{1} \sin \varepsilon+\sigma \omega L \cos \varepsilon\right)^{2}+\left(R_{1}^{2}+\sigma^{2} \omega^{2} L^{2}\right)\left(U^{2}-I_{2}^{2} \omega^{2} L^{2}\right)}}{R_{1}^{2}+\sigma^{2} \omega^{2} L^{2}},
$$

$$
\begin{aligned}
& M=m p L I_{1} I_{2} \sin \varepsilon, \\
& P=m \omega L I_{1} I_{2} \sin \varepsilon, \\
& \operatorname{tg} \phi=\frac{\omega L\left(\sigma I_{1}+I_{2} \cos \varepsilon\right)}{I_{2} \omega L \sin \varepsilon+I_{1} R_{1}} .
\end{aligned}
$$

\section{CHARACTERISTICS OF THE SBL MOTOR}

Equations (1-4) allow the characteristics of an SBL motor to be calculated in the operating mode $\theta=$ const changing the value of angular frequency $\omega$ within the whole range (Fig. 1) ${ }^{1}$. As seen in Fig. 2, angle $\theta$ affects significantly the mechanical characteristics of such a motor.

Characteristics of SBL motor for the operation mode $\varepsilon=$ const are shown in Figs. $3-4$.

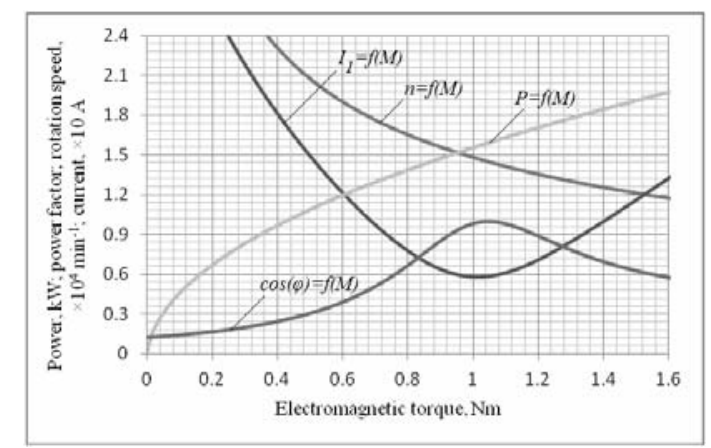

Fig. 1. Characteristics of the SBL motor at $\theta=7^{\circ}$.

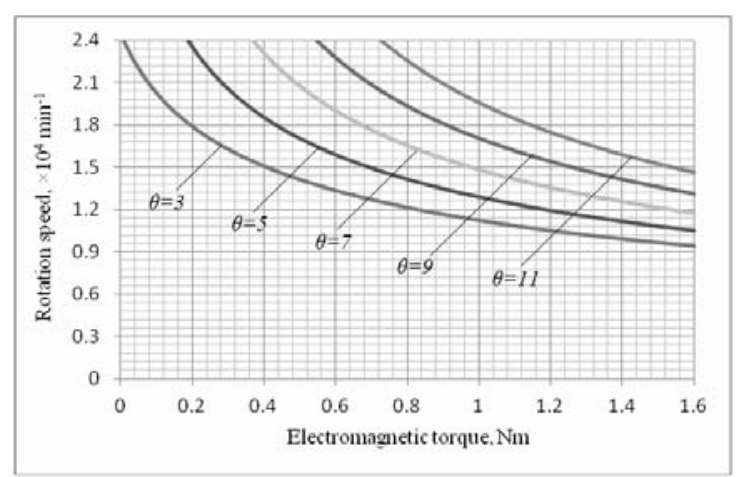

Fig. 2. Mechanical characteristics of the SBL motor at different $\theta=$ const values.

\footnotetext{
1 Figures 1-4 demonstrate the characteristics of a three-phase SBL motor fed from a single-phase AC circuit through a rectifier with the parameters: $U=92 \mathrm{~V}, p=2, L=0.0006 \mathrm{H}, R_{1}=0.25 \Omega$, $\sigma=1.04, I_{2}=50 \mathrm{~A}$. The applied $\mathrm{NdFeB}$ magnets have the parameters: residual induction $B_{r}=1.2 \mathrm{~T}$, thickness $h_{p m}=2 \mathrm{~mm}$, and pole overlapping coefficient $\alpha_{p m}=0.9$.
} 


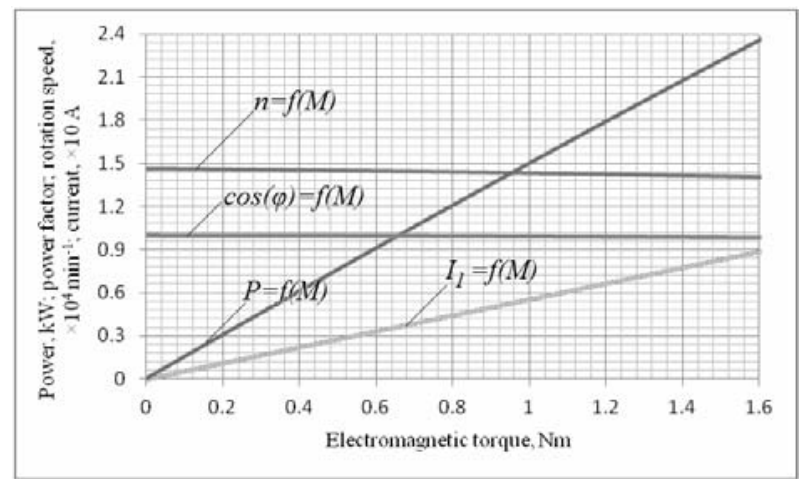

Fig.3. Characteristics of the SBL motor at $\varepsilon=90^{\circ}$.

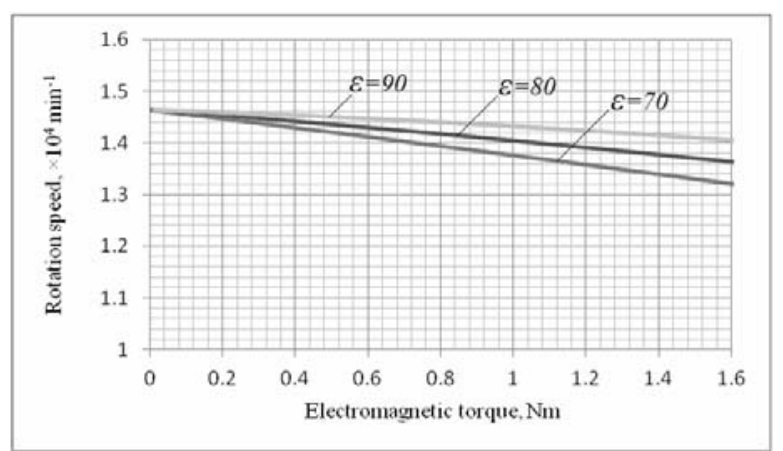

Fig. 4. Mechanical characteristics of the SBL motor at different $\varepsilon=$ const values.

Analyzing the calculated characteristics and Eqs. (1-8), it could be concluded that the range of characteristics in the operating modes under consideration is wide enough. In addition, the mechanical characteristics can be similar to those of DC motors with parallel, series and compound excitation. Choosing correspondingly these characteristics, it is possible to achieve high positive effects - such as limitation of rotation frequency in idle running thus solving some of the problems met at the use of many existing electric hand tools.

Figure 5 shows characteristics taken for an AS REBIR mass-produced electric hand plane with a $1200 \mathrm{~W}$ brushed motor. Comparing them with characteristics shown in Figs. 1 and 3, it can be concluded that SBL motors are applicable in electric hand planes.

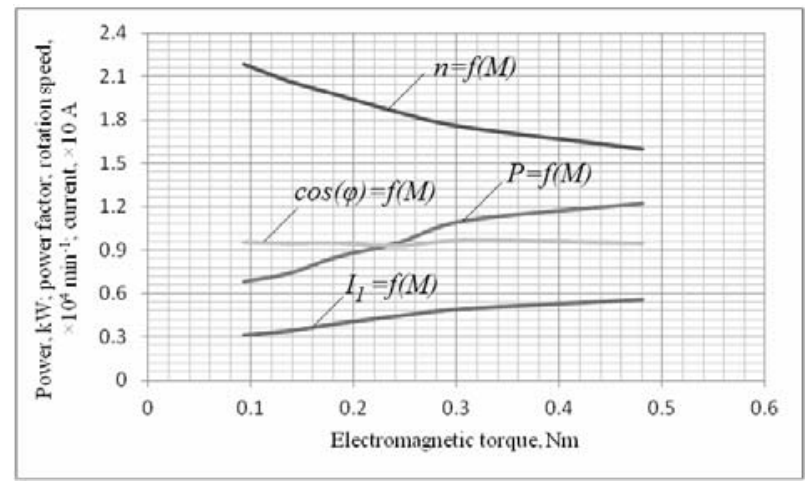

Fig. 5. Characteristics of a mass-produced electric hand plane. 


\section{DESIGN OF SBL MOTOR AND ITS TESTING FOR APPLICATION IN THE ELECTRIC HAND PLANES}

In the existing electric hand planes, for driving a plane cutting bar which is set separately from the motor a brushed motor with belt transmission is used.

Instead, a motor of SBL type having the outer rotor integrated with the cutting bar could be proposed, making it possible to additionally improve the operational features and fully abandon the drive belt transmission. The proposed design of the electric motor with outer rotor is described in [5].

To optimize the design of an electric hand plane with specifically rated power and electromagnetic load, the magnetic field numerical calculations $[6,7]$ could successfully be used. The magnetic field and design of one of the motor versions are shown in Fig. 6 . The dimensions and rated parameters of the produced SBL motor are: the outer diameter $D=63 \mathrm{~mm}$, the active length $l=100 \mathrm{~mm}$, the rated power $P_{N}=1500 \mathrm{~W}$, and the rated rotation frequency $n_{N}=13000 \mathrm{~min}^{-1}$

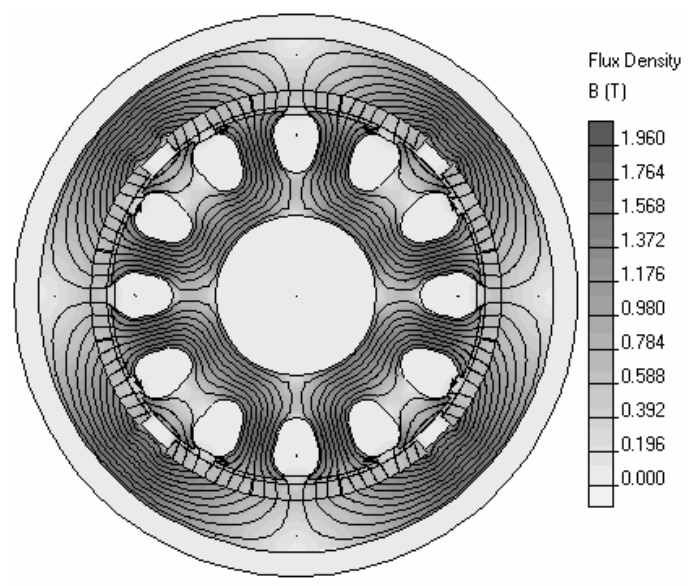

Fig. 6. Magnetic field of the motor with outer rotor.

The characteristics taken for comparison of the optimized experimental SBL motor with the calculated versions are shown in Fig. 7. These are obtained at $\varepsilon=90^{\circ}$ and $I_{2}=50 \mathrm{~A}$, and at a voltage gradually decreasing from $U=105 \mathrm{~V}$ to $U=64 \mathrm{~V}$ with increasing load.

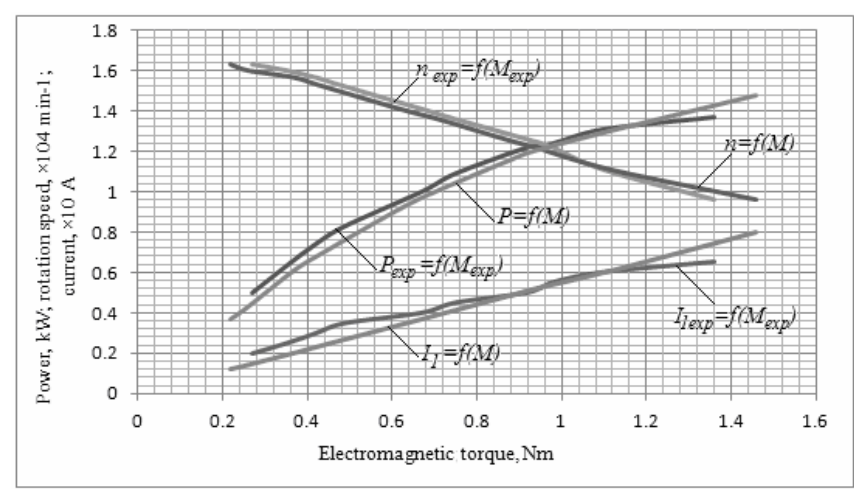

Fig. 7. Calculated and experimental characteristics of the SBL motor. 


\section{CONCLUSIONS}

Based on the results obtained in the work, the following conclusions could be drawn:

1. The SBL motor with excitation from permanent magnets possesses a wide range of characteristics which allow for its application in electric hand tools.

2. The equations describing the operation of a synchronous machine in specific modes can be easily applied for the analysis and optimization of SBL motor characteristics and parameters.

3. The proposed design of synchronous motor with outer rotor and excitation from permanent magnets at increased pole overlapping makes it possible to create a drive with high technical and economic indices for electric appliances.

This article has been supported by the European Regional Development Fund, the project "Improvement of competitiveness and effectiveness of the electric motors operating in hand electric tools"

No. 2010/0212/2DP/2.1.1.1.0/10/APIA/VIAA/004.

\section{REFERENCES}

1. Ovchinnikov, N. (2006). Electronically commutated motors and drives on their bases. St. Petersburg: KORONA-Vek (in Russian).

2. Dirba, J. (1997). Specific regimes of synchronous machines. Riga: RTU (in Latvian).

3. Dirba, J., Levin, N., Orlova, S., \& Pugachov, V. (May 2011). Brushless synchronous motors for appliances and power tools. In: Intern. Conf. on Electrical and Control Technologies (ECT2011). Kaunas University of Tehnology (Lithuania), 222-225.

4. Dirba J., Roldugina N., Pugačevs V. (2001). Methodology of permanent magnet brushless DC motor calculation and optimization. Scientific Proceedings of Riga Technical University: Power and electrical engineering. Ser. 4, Vol. 4, 48-53 (in Latvian).

5. Levins N., Dirba J., Brakanskis U., Ketners K., Orlova S., Pugachevs V. (2011). Sinhronā mašiña ar pastāvīgajiem magnētiem. Latvijas Republikas patents LV14335 B, 20.09.2011.

6. User's Guide (2010). QuickField. Finite Element Analysis System. Version 5.7. Denmark: Tera Analysis, Available at: http://www.quickfield.com [Accessed: Nov. 1, 2011].

7. Kukjane, L., Brakanskis, U., \& Dirba, J. (May 2011). Visual Basic for Application Program for the automatic analysis of brushless DC motor magnetic field. In: Intern. Conf. on Electrical and Control Technologies (ECT2011). Kaunas University of Technology (Lithuania), 231-234.

\section{SINHRONO VENTIḶDZINĒJU IZMANTOŠANAS IESPĒJAS ROKAS ELEKTROINSTRUMENTOS}

\section{J. Dirba, L. Lavrinoviča, N. Levins, V. Pugačevs}

Kops avilkums

Aplūkotas sinhronā ventiḷdzinēja izmantošanas iespējas rokas elektriskajos instrumentos. Parādīta sinhronā ventiḷdzinēja spēja nodrošināt plašu raksturlīkṇu spektru. Aplūkota elektriskās ēveles izveidošana, izmantojot bezkontaktu sinhrono ventiļdzinēju ar ārējo rotoru un pastāvīgajiem magnētiem. 